\title{
Accounting for Exchange Transactions: An Alternative Perspective
}

Rodger G. Holland, (E-mail: rholland@fmarion.edu), Francis Marion University Kathleen A. Kaminski, (E-mail: kkaminski@msubillings.edu), Montana State University

\begin{abstract}
This paper presents a simple alternative method of recording exchange transactions that is theoretically superior to the popular gross method and is more informative than either the net or gross method.
\end{abstract}

\section{INTRODUCTION}

$\mathrm{n}$ general, the two basic methods for recording exchange transactions are to record them at gross, and then
account for the discounts that are taken, or record them at net, and adjust for discounts that are not taken (are
lost). Most principles texts cover only the gross method, and some do not even deal with the discount issue at all. Others may mention the discounts but rarely illustrate both methods. At the intermediate level, several texts discuss both methods, but usually note that the gross method is most widely used in practice, for a variety of reasons. Yet both methods are weak in terms of information provided. We will briefly illustrate each method, and then suggest an alternative that is much richer in terms of information provided.

\section{Purchases of Inventory}

To make life simple, we deal only with the periodic method of accounting for inventory in this paper. To extend it to the perpetual system is a straight-forward process. It is interesting to note that while most academicians argue that the net method is theoretically preferable to the gross method, the gross method is most often used in practice. See Table 1 for a list of the books reviewed and the methods covered.

\section{The Gross Method}

This illustration assumes a gross purchase price of $\$ 1,000$ and typical discount terms of $2 / 10, n / 30$. [The appendix demonstrates that this is more than a 37\% rate of interest.] As suggested by the name, the Purchases and Accounts Payable are recorded at the gross amount:

Dr: Purchases

If payment is made within the ten-day discount period, the payment would be recorded:

Dr: Accounts Payable

$\$ 1,000$
Cr: Cash
Purchase Discounts (taken)

If payment is NOT made within the ten-day discount period, the payment would be recorded: 
Dr: Accounts Payable

Cr: $\quad$ Cash
$\$ 1,000$

$\$ 1,000$

The $\$ 20$ discount equals $2 \%$ of the $\$ 1,000$ purchase price and is a reduction awarded for early payment. Whether or not the account is paid within the discount period is a financing decision, not an asset acquisition decision. In essence, the discount is actually an interest charge for not paying within 10 days. However, note that if the discount is not taken this "interest expense" is left in the Purchases account, where it eventually becomes part of cost of goods sold. For all other purchased assets, it is generally recognized that interest charges are NOT appropriate to include as a part of the cost of the asset. Thus, the gross method is inappropriate, from a theoretical point of view.

\section{The Net Method}

Assuming the same typical discount terms of 2/10, net/30, described above, and the same purchase price of $\$ 1,000$, under the net method both parts of the transaction are initially recorded at the net amount:

Dr: $\quad$ Purchases

$\$ 980$

Cr: $\quad$ Accounts Payable

$\$ 980$

If payment is made within the ten-day discount period, the payment would be recorded:

Dr: Accounts Payable

$\$ 980$

Cr: $\quad$ Cash recorded:

If payment in the above example is NOT made within the ten-day discount period, the payment would be
Dr: Accounts Payable
$\$ 980$
Purchase Discounts Lost

Cr: Cash

$\$ 1,000$

The net method has the advantage of recording Purchases at the correct amount, but the explicit recognition of the Purchase Discounts Lost is not popular. The difference between the methods falls within the realm of materiality which "justifies" use of the gross method. However, from the informational point of view both methods are deficient.

The gross method shows the discounts that were taken within a period whereas the net method shows the discounts that were lost within the period. Obviously, each method conveys only part of the story. To evaluate the effectiveness of accounts payable management, within any period we must know the amount of the discounts that were available and the amount of the discounts that were taken, with the difference being the amount that was lost. That can be accomplished by using the net/gross method. 
Table I

Coverage of Net and Gross Methods for Purchases

\begin{tabular}{|c|c|c|c|}
\hline \multirow[b]{2}{*}{ Principles Texts } & \multicolumn{2}{|c|}{ Methods Discussed } & \multirow{2}{*}{ Preferred } \\
\hline & Net & Gross & \\
\hline $\begin{array}{l}\text { Fundamentals of Financial Accounting, by Fred Phillips, Robert Libby, } \\
\text { Patricia Libby, McGraw-Hill/Irwin, New York, NY, } 2006 .\end{array}$ & $\mathrm{N}$ & Y & N/A \\
\hline $\begin{array}{l}\text { Financial Accounting-A New Perspective by Paul Solomon, McGraw- } \\
\text { Hill/Irwin, New York, NY, } 2004 .\end{array}$ & $\mathrm{N}$ & $\mathrm{N}$ & N/A \\
\hline $\begin{array}{l}\text { Financial Accounting, } 9^{\text {th }} \text { edition, by W. Steve Albrecht, James D. Stice, } \\
\text { Earl K. Stice, and Monte R. Swain, Thomason Southwestern, Mason, } \\
\text { Ohio, } 2005 \text {. }\end{array}$ & $\mathrm{N}$ & $\mathrm{Y}$ & N/A \\
\hline $\begin{array}{l}\text { Financial Accounting, } 6^{\text {th }} \text { edition, by Walter T. Harrison, Jr. and Charles } \\
\text { T. Horngren, Pearson/Prentice Hall, Upper Saddle River, New Jersey, } \\
2005\end{array}$ & $\mathrm{~N}$ & $\mathrm{~N}$ & N/A \\
\hline $\begin{array}{l}\text { Financial Accounting, } 4^{\text {th }} \text { edition, by Jerry J. Weygandt, Donald E. Kieso, } \\
\text { and Paul D. Kimmel, John Wiley \& Sons, Inc., New York, NY, } 2005\end{array}$ & & $\mathrm{I}$ & N/A \\
\hline \multicolumn{4}{|l|}{$\begin{array}{l}\text { Financial Accounting, } 2^{\text {nd }} \text { edition, by Rick Antle and Stanley J. Garstka, } \\
\text { Thomson Southwestern, Mason, Ohio, } 2004\end{array}$} \\
\hline $\begin{array}{l}\text { Fundamental Financial Accounting Concepts, } 5^{\text {th }} \text { edition, by Thomas P. } \\
\text { Edmonds, Cindy D. Edmonds, Frances M. McNair, Philip R. Olds, and } \\
\text { Nancy W. Schneider, McGraw-Hill/Irwin, New York, NY } 2006\end{array}$ & $\mathrm{~N}$ & $\mathrm{Y}$ & N/A \\
\hline \multicolumn{4}{|l|}{ Intermediate Texts } \\
\hline \multicolumn{4}{|l|}{$\begin{array}{l}\text { Intermediate Accounting, updated Third edition, by J. David Spiceland, } \\
\text { James F. Sepe, and Lawrence A. Tomassini, McGraw-Hill/Irwin, New } \\
\text { York, NY, 2004. }\end{array}$} \\
\hline $\begin{array}{l}\text { Intermediate Accounting, } 11^{\text {th }} \text { edition, by Donald E Kieso, Jerry J. } \\
\text { Weygandt, and Terry D. Warfield, John Wiley and Sons, Hoboken, NJ, } \\
2005\end{array}$ & $\mathrm{Y}$ & $\mathrm{Y}$ & $\begin{array}{l}\text { Net/ } \\
\text { Gross used } \\
\text { in practice }\end{array}$ \\
\hline $\begin{array}{l}\text { Financial Accounting, } 8^{\text {th }} \text { edition, by Belverd E. Needles, Jr., and Marion } \\
\text { Powers, Houghton Mifflin Company, Boston, MA, } 2004 .\end{array}$ & $\mathrm{N}$ & $\mathrm{Y}$ & N/A \\
\hline \multicolumn{4}{|l|}{$\begin{array}{l}\text { Financial Accounting in an Economic Context, } 6^{\text {th }} \text { edition, by Jamie Pratt, } \\
\text { John Wiley and Sons, Hoboken, NJ, } 2006 .\end{array}$} \\
\hline $\begin{array}{l}\text { Accounting-Information for Business Decisions, } 2^{\text {nd }} \text { edition, by Billie M. } \\
\text { Cunningham, Loren A. Nikolai, and John D. Bazley, Thomson } \\
\text { Southwestern, Mason, Ohio, } 2004 .\end{array}$ & $\mathrm{Y}$ & $\mathrm{Y}$ & Net \\
\hline
\end{tabular}

\section{The Net/Gross Method}

The net/gross method combines elements of the two methods. It records Purchases at net and Accounts Payable at Gross, with Purchase Discounts Available filling in the difference:

Dr: $\quad$ Purchases

Purchase Discounts Available

Cr: $\quad$ Accounts Payable
$\$ 980$

20

In this hybrid method recording payments (whether within the discount period or late) is exactly the same as with the widely used gross method. The only procedural change is to initially record the purchase net of the discount, with the amount of the potential discount recorded in Purchase Discounts Available.

It should be clear that Purchase Discounts Available but not taken become Purchase Discounts Lost. Assuming total Purchase Discounts Available of \$200,000 during the year and total Purchase Discounts Taken of \$196,000 the first 
step in the closing process should be:

\section{Dr: $\quad$ Purchases Discounts Taken Purchase Discounts Lost}

Cr: $\quad$ Purchase Discounts Available
$\$ 196,000$

4,000

$\$ 200,000$

The Purchase Discounts Lost would then be treated as a financing cost when closed. Furthermore, we believe it would be reasonable to deduct this on the tax returns for the current year, not when the goods were sold. This timing difference could be substantial, depending on the size of the company and the ineffectiveness of the payment process. But more significantly, look what this simple change achieves. Now, and only now, can the complete picture be seen---we know the total discounts that were available, those that were taken, and those that were lost. This simple change enhances the collection of information and facilitates better management.

The manager in our example lost two percent of the discounts that were available. Whether that is good or bad is another issue, but at least that issue can now be addressed. Neither traditional system allows the percentage of discounts taken to even become an element to be considered. In short, this low cost change to our accounting system allows us to mine the data for more complete information to make better decisions. Now we turn our attention to sales.

\section{Sales}

For sales, both the net and gross method are often illustrated in intermediate texts with no principles text covering the net method (see Table 2). As usually alluded to, the gross method is most common in practice. Given that these transactions are simply the inverse of the others, for brevity we will not illustrate the net or gross method.

If the acquisition of inventory employs the net/gross method, it follows that the gross/net method is used for recording sales. Assuming the same $\$ 1,000$ transaction with us being on the selling end, the entry would be:

Dr: $\quad$ Accounts Receivable

$\$ 1,000$

$\begin{array}{llr}\text { Cr: } & \text { Sales } & \$ 980 \\ & \text { Sales Discounts Offered } & 20\end{array}$

Then if the account is received within the discount period, the entry would be:

Dr: Cash \$980

Sales Discounts Taken 20

Cr: $\quad$ Accounts Receivable $\$ 1,000$

If the account is not settled until after the discount period, the entry would be:

Dr: Cash $\$ 1,000$

Cr: $\quad$ Accounts Receivable $\$ 1,000$

The Sales Discounts Offered but not taken become an additional revenue. This simple illustration is only the tip of the iceberg, however, since a variety of discounts are often offered in an effort to stimulate sales. This simplistic change enables small companies to obtain better information for determining the effectiveness of their discount and/or sales promotion programs. 
Table II

Coverage of Net and Gross Methods for Sales

\begin{tabular}{|c|c|c|c|}
\hline \multirow[b]{2}{*}{ Principles Texts } & \multicolumn{2}{|c|}{ Methods Discussed } & \multirow{2}{*}{ Preferred } \\
\hline & Net & Gross & \\
\hline $\begin{array}{l}\text { Fundamentals of Financial Accounting, by Fred Phillips, Robert Libby, } \\
\text { Patricia Libby, McGraw-Hill/Irwin, New York, NY, } 2006 .\end{array}$ & $\mathrm{N}$ & $\mathrm{Y}$ & N/A \\
\hline $\begin{array}{l}\text { Financial Accounting-A New Perspective by Paul Solomon, McGraw- } \\
\text { Hill/Irwin, New York, NY, } 2004 .\end{array}$ & $\mathrm{N}$ & $\mathrm{N}$ & N/A \\
\hline $\begin{array}{l}\text { Financial Accounting, } 9^{\text {th }} \text { edition, by W. Steve Albrecht, James D. Stice, } \\
\text { Earl K. Stice, and Monte R. Swain, Thomason Southwestern, Mason, } \\
\text { Ohio, } 2005 \text {. }\end{array}$ & $\mathrm{N}$ & $\mathrm{Y}$ & N/A \\
\hline $\begin{array}{l}\text { Financial Accounting, } 6^{\text {th }} \text { edition, by Walter T. Harrison, Jr. and Charles } \\
\text { T. Horngren, Pearson/Prentice Hall, Upper Saddle River, New Jersey, } \\
2005\end{array}$ & $\mathrm{~N}$ & $\mathrm{~N}$ & N/A \\
\hline $\begin{array}{l}\text { Financial Accounting, } 4^{\text {th }} \text { edition, by Jerry J. Weygandt, Donald E. Kieso, } \\
\text { and Paul D. Kimmel, John Wiley \& Sons, Inc., New York, NY, } 2005\end{array}$ & & I & N/A \\
\hline $\begin{array}{l}\text { Financial Accounting, } 2^{\text {nd }} \text { edition, by Rick Antle and Stanley J. Garstka, } \\
\text { Thomson Southwestern, Mason, Ohio, } 2004\end{array}$ & & & \\
\hline $\begin{array}{l}\text { Fundamental Financial Accounting Concepts, } 5^{\text {th }} \text { edition, by Thomas P. } \\
\text { Edmonds, Cindy D. Edmonds, Frances M. McNair, Philip R. Olds, and } \\
\text { Nancy W. Schneider, McGraw-Hill/Irwin, New York, NY } 2006\end{array}$ & $\mathrm{~N}$ & $\mathrm{~N}$ & N/A \\
\hline \multicolumn{4}{|l|}{ Intermediate Texts } \\
\hline $\begin{array}{l}\text { Intermediate Accounting, updated Third edition, by J. David Spiceland, } \\
\text { James F. Sepe, and Lawrence A. Tomassini, McGraw-Hill/Irwin, New } \\
\text { York, NY, 2004. }\end{array}$ & $\mathrm{Y}$ & $\mathrm{Y}$ & $\begin{array}{l}\text { Net/ } \\
\text { Gross used } \\
\text { in practice }\end{array}$ \\
\hline $\begin{array}{l}\text { Intermediate Accounting, } 11^{\text {th }} \text { edition, by Donald E Kieso, Jerry J. } \\
\text { Weygandt, and Terry D. Warfield, John Wiley and Sons, Hoboken, NJ, } \\
2005\end{array}$ & $\mathrm{Y}$ & $\mathrm{Y}$ & $\begin{array}{l}\text { Net/ } \\
\text { Gross used } \\
\text { in practice }\end{array}$ \\
\hline $\begin{array}{l}\text { Financial Accounting, } 8^{\text {th }} \text { edition, by Belverd E. Needles, Jr., and Marion } \\
\text { Powers, Houghton Mifflin Company, Boston, MA, } 2004 .\end{array}$ & $\mathrm{N}$ & $\mathrm{Y}$ & N/A \\
\hline $\begin{array}{l}\text { Financial Accounting in an Economic Context, } 6^{\text {th }} \text { edition, by Jamie Pratt, } \\
\text { John Wiley and Sons, Hoboken, NJ, } 2006 .\end{array}$ & $\mathrm{Y}$ & $\mathrm{Y}$ & Gross \\
\hline $\begin{array}{l}\text { Accounting —Information for Business Decisions, } 2^{\text {nd }} \text { edition, by Billie M. } \\
\text { Cunningham, Loren A. Nikolai, and John D. Bazley, Thomson } \\
\text { Southwestern, Mason, Ohio, } 2004 \text {. }\end{array}$ & $\mathrm{N}$ & G & N/A \\
\hline
\end{tabular}

\section{SUMMARY}

The "proper" recording of transactions is accomplished through use of the net methodology, but the net/gross for asset acquisition and gross/net for selling assets accomplishes the same correct valuation while providing much more information. In essence, even small firms can obtain some of the benefits of data mining by a simple restructuring of the way exchange transactions are recorded. 


\section{APPENDIX}

Unfortunately many firms, particularly small ones run by entrepreneurs, do not understand the importance of taking advantage of purchase discounts because the discount is improperly viewed. The two percent discount is viewed as minimal without realizing that this is a) two percent of the total rather than two percent of the principle and b) the period of time for this borrowing is only 20 days with an interest rate of over $37 \%$.

Assuming the same example as in the text, we can write the final payment as:

$\$ 1,000=\$ 980$ (principle) $+\$ 20($ interest $)$

Given that the amount of interest is equal to the interest rate (i) multiplied by the amount of time (t), we have:

$$
\$ 20=\mathrm{i} * \$ 980 * \mathrm{t}
$$

The amount of time is 20 days---the company can pay at the end of 10 days and still get the discount but should pay at the end of 30 days in any event. Thus, the difference of 20 days is the time frame. Substituting for time we have:

$\$ 20=\mathrm{i} * \$ 980 *(20 / 365)$

Finally, rearranging terms and solving for i we have:

$\mathrm{i}=(\$ 20 / \$ 980) *(365 / 20)$

$\mathrm{i}=37.24 \%$

Most firms can arrange a line-of-credit at terms more favorable than $37 \%$, but some do not realize the magnitude of these "small discounts."

\section{REFERENCES}

1. Albrecht, Steve, James D. Stice, Earl K. Stice, and Monte R. Swain. Financial Accounting, 9th ed. Mason, OH: Thomason Southwestern, 2005.

2. Antle, Rick and Stanley J. Garstka. Financial Accounting 2nd ed. Mason, Oh: Thomson Southwestern, 2004.

3. Cunningham, Billie M., Loren A. Nikolai, and John D. Bazley. Accounting-Information for Business Decisions, 2nd ed. Mason, OH: Thomson Southwestern, 2004.

4. Edmonds, Thomas P., Cindy D. Edmonds, Frances M. McNair, Philip R. Olds, and Nancy W. Schneider, Fundamental Financial Accounting Concepts, 5th ed. New York: McGraw-Hill/Irwin, 2006.

5. Harrison, Walter T., Jr. and Charles T. Horngren. Financial Accounting, 6th ed. Upper Saddle River, NJ: Pearson/Prentice Hall, 2005.

6. Kieso, Donald E., Jerry J. Weygandt, and Terry D. Warfield. Intermediate Accounting, 11th ed. Hoboken, NJ: John Wiley and Sons, 2005.

7. Needles, Belverd E., Jr. and Marion Powers. Financial Accounting, 8th ed. Boston: Houghton Mifflin Company, 2004.

8. Phillips, Fred, Robert Libby, and Patricia Libby. Fundamentals of Financial Accounting. New York: McGraw-Hill/Irwin, 2006.

9. Pratt, Jamie. Financial Accounting in an Economic Context, 6th ed. Hoboken, NJ: John Wiley and Sons, 2006.

10. Solomon, Paul. Financial Accounting-A New Perspective. New York: McGraw-Hill/Irwin, 2004.

11. Spiceland, J. David, James F. Sepe, and Lawrence A. Tomassini. Intermediate Accounting, $3^{\text {rd }}$ ed. New York: McGraw-Hill/Irwin, 2004.

12. Weygandt, Jerry J., Donald E. Kieso, and Paul D. Kimmel. Financial Accounting, 4th ed. New York: John Wiley \& Sons, Inc., 2005. 